\title{
Between the Single Market and the European Union
}

\author{
Diarmuid Rossa Phelan, Brasenose College (Oxford)
}

You can't make an omelette without breaking eggs.

- Vladimir Ilich Ulyanov (Nikolai Lenin), and Jack Nicholson (the Joker),

Barman

The sovereignty of this House is not a matter that is up for grabs-that is perfectly clear.

-Prime Minister Major, House of Commons ${ }^{\prime}$

The European Community (EC) is poised between 31 December 1992 , the target date for the completion of the internal market, and the coming into force of the Maastricht Treaty on European Union (TEU) upon ratification by Germany. ${ }^{2}$ The TEU presents integrationists with the constitutional structures for a decisive move to federation whose legal foundations currently run far deeper than popularly represented. Consequently there is urgent need for informed public participation in the shaping of European structures. Furthermore, there is growing discussion in the EC institutions on proposals for a European Constitution directly enacted by Union citizens. ${ }^{3}$ At the same time, the recent currency upheavals culminating in the weakening of the exchange rate mechanism raises questions of the stability of the EC's foundations. ${ }^{4}$ This article aims to provoke debate by raising arguments on a series of issues in the light of the legal approfondissement and in reaction to it. Section I summarizes the constitutional advance of the EC prior to the TEU towards the legal system of a federal nation. Section II raises the issues of spill-over, nationalism, democratic deficit, debate, referenda, socíal marginalization, and rights in the light of this undiscussed approfondissement. Section III examines some of the effects of the TEU on the lines of development considered in the first two sections.

\section{The Rubicon}

Since the Treaty of Rome (1957), the $\mathrm{EC}$ has been suspended between a confederation and a federation. The EC has been explained with characteristic clarity to be sui generis; it is, above all, a creation of law. Constitutional lawyers who have taken seriously the implications of the claims of EC law, as interpreted by the Court of Justice of the European Communities (ECJ), have been steadily lining the banks of a legal Rubicon. This Rubicon is the legal division between the constitutional conception of a European state and a sui generis community. In the sui generis community, constitutional lawyers can uneasily claim that their national constitutions are still the basic law. In a European state such claims will no longer be possible. Judge Barrington of the Court of First Instance clearly stated: "It has been said that when great changes are taking place in the exercise of power in society, lawyers are the first people to spot the significance of what is happening. The general public is not disturbed provided the forms of authority remain the same. The lawyer, in his day to day practice, must be sensitive to where power actually lies." "There are bridges over the Rubicon for services, workers, and capital. National constitutional lawyers, on the other hand, face compulsory baptism.

The EC law dynamic has always been ahead of the popular (mis)conception of the EC: "Article I of the Treaty of Rome establishes the European Economic Community. The remaining 247 Articles of the Treaty are concerned with technical arrangements for operating such a community. Yet economics is not really what the Treaty is about." 6 The authors of those 247 articles found this somewhat surprising. Indeed, in the case of van Gend en
Loos, three of the six menber states submitted briefs stating that the Treaty was a compact between states. "Wrong," said the Court. The member states had underestimated the importance of creating an independent institution with the poucr to make binding interpretations of the law." According to the Court: "Hie Community constitutes a new legal order of international law for the benefit of which the states have liniited their sovereign rights, albeit within limited fields, and the subjects of which compromise not only Member States but also their nationals.""

The ECJ has subsequently laid down the following additional constitutional principles. EC law is supreme, even over subsequent contradictory national legislation. "It must be applied uniformly through. out the Community. ${ }^{\text {In }}$ The economic principles contained in the articles on the free movement of goods. Workers, services and the freedom of establishment apply supremely. uniformly, and directly without the need for activity by the EC legislative organs (the Council and the Commission)." The express wording of the articles which create the free movement principles confines their application to discriminatory national laws. Thanks to the ECJ, these principles now overrule even nondiscriminatory national laws which impede their realization. "Dircctives, according to Article 189, must he implemented by the member states and are binding only as to the result to be achieved. According to the Court, not only may unimpleniented . directives be invoked effectively 10 invalidate the relevant national legislation in litigation between private parties, but member states must also provide a remedy in damages where non-implementation has caused loss."

In short, the Treaties are the "con- 
stitutional charter" of the Community, ${ }^{14}$ and the fundamental constitutional structures of EC law tend lowards those of a national legal system. The phrase "European Union" has already been employed in the ECJ's jurisprudence, the Single European Act, and the Solemn Declaration of Stuttgart. 1 The validity of a national society's basic value choices of a moral (e.g., concerning pornography) or a cultural (e.g., Sunday trading) character are tested by EC law. ${ }^{16}$ When national constitutional commitments of the most fundamental kind, be they the sovereignty of parliament or human rights, conflict with EC law they can be overridden. ${ }^{17}$ There is simply no way a uniform, supreme, directly applicable, and encompassing legal system can sidestep the varying fundamental commitments of twelve states. There cannot be nations within a nation; there can be only one perfecta communitas, or none at all. EC legal logic says the Rubicon must be crossed.

The ECJ has successfully avoided such conflicts while establishing national constitutional structures. Is there a way to continue through the use of derogations or subsidiarity? As regards derogations, these were often claimed by member states seeking to bluff their way out of the economic obligations of the treaties while trying to hold on to the benefits-legal mercantilism. Consequently, the tests which the ECJ evolved in response closely restrict derogations; they apply irrespective of the ground of derogation. Some of these tests employ EC conceptions of the public interest, necessity in a democratic society, and the proportionality of the restriction of an EC right by a national constitutional right or value -concepts which make sense only in a complete political community. ${ }^{18}$ In short, national concepts.

W'hat about subsidiarity? As in a magic mirror in a horror film, one sees one's own vision of Europe in subsidiarity. The indeterminacy of the concept presents commentators with the opportunity to build their own church. Juridically, however, there are two primary possibilities. First, the ECJ may not treat subsidiarity as a juridical constitutional concept; it could characterize it as a political principle. Second, the Court may determine the juridical content of the principle, probably in the integrationist vein highlighted above. Any time the constitution of the EC has been clarified, it has become more federal. The area of application of subsidiarity applies only to areas where the Union shares competences with the member states (Article 3(b) (TEU)), not in areas of exclusive competence such as the fundamental freedoms, competition, etc. There is little in life, from language requirements to euthanasia, which does not effect a market economy, and thus potentially conflicts with principles within the Union's exclusive competence. There is the chance that subsidiarity will be used to avoid conflicts in emotive areas in order to better construct the norms of federalism-which will be well established enough to crack the eggshell of national constitutions when the time comes. The key question at the Rubicon is independent self-determination, a question which subsidiarity appears at best to skip, if not to answer in the negative.

\section{II. "Belling the Cats" 19}

From the perspective of EC law, the $\mathrm{EC}$ is very close to a disguised, federal nation; politically, this is not the case. Given the depth of legal federalization, several stalking issues need to be "belled" in the public debate on the future shape of Europe.

One argument has been that economic integration spills over into political and social areas. Because economic principles are supreme, it is necessary to integrate these political and social areas in order to preserve them from being shaped by economics. Quite incredibly, the Treaty on European Union (TEU) which advances greater integration adds a new Title IX and Article 128 which proclaims a Europe of flowering of cultures. Culture through economics, diversity through harmonization! But the contrary argument, that economic integration should be limited and informed by important social and political characteristics in member states, that economics is a means to securing the various political goals of the nations of Europe, is termed "anti-European." This epithet assumes that there is only one truc European idea, whose content and value has been agreed: it excludes debate. "Pro-European" is often joined to "the need for a democratic Europe," trendy phrases which have become at best the very pith of demagoguery, perhaps the forerunner of oligopoly. One of the few lawyers in 30 years of EC law to mount a sustained critique of the EC was quickly shot down as un-European. ${ }^{n}$

One could argue that a European can see the future as peace between the peoples of Europe, without having so little respect for them as to make them one people. This is not "narrow nationalism." Some extreme historical manifestations of nationalism tell us more about the tendencies of human nature than about the destructiveness of the social and legal arrangement of nationhood per se. The same tendencies and conditions can regroup around "Europe." Has patriotism, a concept involving duties, concern, and allegiance to other than self. become a despised virtue contrary to the European ideal? Do "true Europeans" really think that the controlling element of selflessness in patriotism can be preserved but transferred by successful marketing, like freely moving capital, to

Brussels?

One can also raise questions on the "democratic deficit." This generally refers to the absence of transparcncy in the workings of the Conmission and Council of Ministers, and the restricted role of the directly elected European Parliament (EP) in the legislative process. Using the emotive term "democratic deficit" to encourage reform of the EC disguises the assumption on which it rests: if the legitimacy of its supreme legal power is drawn directly from the people. bypassing the nations, then a federal nation will be formed. Even if another EC institution was created along the lines of the United States Senate, the bicameral legislature would remain within the structure of a federal state. ${ }^{21}$ The democratic deficit could thus be solved by the effective destruction of national parliaments' legislative powers and the influence of national governmerits. It 
is one of the great contradictions of EC rhetoric that a democracy is assumed to be the goal of an undemocratic process of power transfer. The immediate democratic deficit is the absence of articulate debate on whether or not national democracies should be overridden by a central European state. If the peoples of Europe knowingly answer yes, then the second step may be to debate the absence of democratic institutions therein and the need, if any, for a senate or for the role of the Council to be reduced to this function. One of the hallmarks of the European debate is its willingness to leapfrog the first step.

Thatcher's "No, no, and no" and aggressive newspaper headlines do not constitute articulate debate. Nor do they constitute an attractive alternative to the urbane, organized European propaganda (the word "propaganda" is used without negative connotations). It is not enough to sense that something is rotten in Brussels. Academia has failed to be impartial: there has been no concerted movement in disintegration theory or states' rights. As regards law, it is almost exclusively EC and not constitutional lawyers who write on EC law. Although this is understandable, it leaves the field free from its natural critics. Even when EC lawyers are inclined to criticism, integrationist accounts of the law will be predictive and cutting edge, whereas arguments of caution will be old-hat and consequently less attractive to publishers. As regards economics, despite the lack of independence of the Cecchini Report (1988) on "the cost of non-Europe," which was requested by the Commission to support their initiative, economists refrained from widespread calls for a funded study to critically examine these assertions or propose alternatives.

As regards popular debate, the referenda in France, Ireland, and Denmark are good examples. In Paris, corporate-sponsored posters jostled for space to declare for Europe; in the country fields in the Isle de France, handpainted boards propped against scarecrows appealed to passing motorists for "Non a Maastricht." In Ireland, the crucial question of whether the content and effectiveness of human rights upheld by national courts should be ultimately decided at national or at EC level was completely lost in the emotional debate surrounding the rights at issue. The government followed the established practice of threatening economic extinction. In Denmark at least the text of the Treaty was widely available. But it is also the most worrying example of all. They voted No. "Wrong," said "Europe." They cannot vote no-the Treaty was resubmitted with a superior marketing campaign. There is no real change in the legal effects of its provisions, although the implications of some are spelled out. ${ }^{22}$ If the member states hade made real changes they would have been obliged to renegotiate, and where applicable reratify, the TEU; this would have delayed the march towards closing the "democratic deficit." In the United Kingdom the government approach was simple-to avoid a referendum. If this is how national systems handle debates of constitutional importance, perhaps nothing worth losing is at stake. At least the $\mathrm{EC}$ institutions believe in themselves.

Integration has been successfully advanced by the skillful effort of the ECJ and the Commission. One can say that integration has greatly contributed to stability amongst the member states, particularly in controlling the belligerent nations of the first half of the century. But one can also query whether in this process integration has attained an independent value. What one must ask is whether the EC has succeeded where the member states have failed to deliver on the post-war promise; whether unemployment, the inequitable division of resources, marginalization, loss of community, anomie have been alleviated; whether the EC has elevated to the status of constitutional value the same failed market principles free from the qualifications of social and legal context of the member states; and whether the EC paradoxically follows the reduction, typical of world communism, of social and political thought to economic analysis. Some disparities in societies appears inevitable. Capitalism undoubtedly encourages disparities in wealth amongst citizens within a society. Adopting market econom- ics at the European level not only entrenches this division but also encourages disparities between socicties; indeed, the size of the disparity becomes the yardstick of the political worth of a society. Capitalism on stilts. The power 10 correct soxial evils is dispersed between the $\mathrm{E}: \mathrm{C}^{\circ}$ and the member states or simply placed in the invisible hand, and no one can be held accountable for failure. $\wedge$ failed generation of national politicians has deprived its successors of the power to try. Politicians, constitutional lawyers, economists all keen their status. No one kecps respon)sibility.

Arguments countering these claims tend towards supplying reasons for greater integration, for the transfer of powers, for believing that what has not worked at national level will work at EC level. If it doesn't, the "Brussels burcaucrats" can be blamed. An attractive supplenientary argument is that EC law grants additional rights to individuals. Fveryone wants rights. In general, situations may occur where ECJ decisions create rights sought by some minurities in some member slates who cannot secure these rights through democratic means. This inability is perhaps because of the value accorded to conflicting rights, or perhaps hecatise of the lethargy of the national system. Recognition of rights may or may not constitulc social progress, according to one's viewpoint and the rights in question. But when a decision deprives a right. even a majority in a membet stafc cannot change it without calling into question the EC's legal bases of supremacy, uniformity, and direct applicability (Section 1, supra). Now is the time for questions.

There is a tendency to nroclaim that EC law rights liberate Europeans from the oppressive restraints of national governments. Two points need be noted here. In the first place, any EC law overrules all national law of whatever nature. Trumpeters of EC law rights tend to omit to refer to corresponding duties or the limitation of conflicting national rights and powers which may serve equal or greater human values. An outstand. ing example of disingenuity was given by the Irish government's marketing posters during the TEU 
referendum: "Guarantee the right to travel, the right to information, and the right to life of the unborn. Vote yes." These rights were all already guaranteed under the national constitution: what had to be resolved was their relative values in cases of conflict. Against whom were they to be guaranteed? Were the Irish agreeing to ask the EC to guarantee rights against themselves? In the second place, courts and treaties can print rights like treasuries can print money. ${ }^{23}$ For example, one may accept the idea of conferring an EC law right on non-nationals (soon to be European citizens) to vote in local elections. This must be weighed against the dilution of the effectiveness of a national's right to vote in his own elections.

\section{The Treaty on European Union}

It is unwise to predict the meaning of the TEU until the ECJ has interpreted it after ratification. Ratifiers are to an extent thus debating blindly. However, in the light of the above, five points in the TEU should be mentioned here which continue the transformation into a European federal nation:

1. Article $C$ declares that the Union shall respect and build on the " 'acquis communautaire.' "This includes the landmark constitutional decisions of the ECJ to which the national peoples give the seal of approval either directly by referendum or through their representatives in parliament.

2. The ECJ has already developed a remedy in damages for private litigants against member states for breach of EC law obligations (Francovich). ${ }^{24}$ Article 171 allows the ECJ to impose a fine itself directly on the member state if the Commission sues for failure to comply with a prior judgment.

3. Article B states that an objective of the Union is "to strengthen the protection of the rights and interests of the nationals of its member states through the introduction of a citizenship of the Union." This is of course an extremely important federalizing concept which both the Danish people and the French picked up on: "European citizenship opens the way to European sovereignty, which will be incompatible with national sovereignty." 25 It leaves the meaning of citizenship ambiguous at both the Union and the member state level. Article B refers to only strengthening rights, which is impossible: the single concept of citizenship of supreme EC law must conflict in parts with twelve different national concepts of citizenship. It is difficult to overestimate its significance; the "symbolism" is constitutional.

4. The directly elected European Parliament (EP) is given a limited role as legislator. For example, under Article $189(\mathrm{~b})(\mathrm{c})$ it has the power to veto measures adopted under certain articles by the Council and Commission. Before these regulations, directives, and decisions come into force, under Article 191 the President of the EP must sign together with the President of the Council. Once again, this development may or may not be welcomed. An increase in the role of the EP increases the power of Europeans qua Union citizens who elect it. The flipside is a decrease in the power which Europeans qua Portuguese, British, German, confer to their elected representatives who will form a national government with both powers at home and control of the EC legislature via the Council.

5. The Protocol on the Transition to the Third Stage of EMU declares "the irreversible character of the Community's movement to the third stage of Economic and Monetary Union." This touches on a key issue of very advanced conversion to a United States of Europe-indissolubility. It is to be noted that Protocols (as distinct from Declarations) have the same force as Treaties by virtue of Article 239 EEC. The U.K. and Denmark have opt-outs if they ratify.

Ratification of the TEU is a landmark on the route to the dissolution of nationhood in the Rubicon of EC constitutional law. The TEU means what it says, and more besides, as the development via interpretation and application of the Treaty of Rome proves. The TEU accentuates the existing tension between two levels of quasi-nations-the member states and the Union. This situation will give rise to cases of conflict before the ECJ which is obliged in resolving them "to ensure that in the interpretation and application of the Treaty the law is observed." The ECJ has proved itself, by the exercise of skill and ingenuity in the past. capable of this great task, but lie peoples of the member states or at least their representatives in parliament must realize the implications of such interpretation. Politicians are generally concerned with the power of decision making; they have overlooked the fact that law is concerned primarily with normative order. Questions of state sovereignty are an area of overlap of these perspectives. ${ }^{2 h}$ Politicians may realize the oversight when Francovich type actions cause charges an public funds. By then it may be too late for debate because the normative order after the TEU will have changed. The ECJ's interpretation of the TEU after ratification will tell us whether the Rubicon has been crossed. The direction in the FEU is clear.

Those who wish the European project to succeed, and to eindure, must point to two defects. First, this level of integration provides an obstacle to expansion of the Union. Even if expansion can succeed, there will be a certain, perhaps unintentional imposition of values on poorer. recently independent countries. These will be presented with a fait accompli. Does this square with the member states' obligations of wishes with respect to, for example, the countries of Central and Eastern Europe, with which the EC has concluded trade, cooperation and association agreements, and to Turkey?" The EC cannot gloss over this point by non-sequiturs such as the following: "The European Community has to proceed towards a federal-type European Union, now that there are several actual or potential applicants waiting to join." $2 \pi$

Second, the following related problems in the nedigree of the Union may misshape it. There are difficulties in escaping from an origin where market economics is raised to the level of constitutional principic (c.g., Article 102a (TEU)). Further, the proponents of the project of European integration have secmed ready where necessary to sacrifice both the human ends protected in 
national constitutional law and the democratic processes os informed consent in national politics in order to strengthen the means of integration. The proponents assure us that the end of this integration is a European, federal nation which will be the paradigm of "politically correct" democracy. Democracy does not spring fully armed from the head of a bureaucrat; uniform political correctness and a flowering of diverse cultures are irreconcilable. The lack of security which comes from the absence of an unequivocal mandate from informed publics in whose name the project is, or should be, undertaken, forces federalists to integrate faster and deeper. To break the back of national constitutions, of nations, and to present European citizenry with a fail accompli before they fully realize it is not an auspicious rebirth for Europe; nor is the prodigy likely to last. The peoples of Europe have this great right: to determine their future.

\section{Notes}

-The author wishes to thank Professor Bernard Rudden of the University of Oxford for his comments. Responsibility remains the author's.

1. H.C. Deb. vol, 207, col. 493 (12 May 1992).

2. The target date is set by Article 13 of the Single European Act. The coming into force of the TEU occurs "on the first day of the month following the deposit of the instrument of ratification by the last signatory State to take this step" - Article R (TEU). The text used is that signed with the "Final Act" in Maastricht on 7 February 1992 , Agence Europe No. 1759/60, 7 February 1992. Ratification by Germany depends on the decision of the Federal Constitutional Court, which is expected in October 1993, on the constitutionality of the treaty.

3. Rapporteur Oreja, Projet de document de Iravail sur la siralégie relarive d l'élaboralion et la mise en oeuvre de la Constifution de I'Union Europeene, Parliament Europeen 204.541. March 16, 1993, considered by the Institutional Commission of the European
Parliament, Compte Rendu Sommaire. Commission Institutionnelle, SP (93) 1189, April 27-28, 1993

4. Communique by the Council of Finance Ministers and Central Bank Gover. nors of the EC, Brussels, August 2, 1993, on the decision to temporarily widen the obligatory marginal intervention thresholds of the participants in the Exchange Rate Mechanism of the European Monetary System to plus or minus $15 \%$ around the bilateral central rates.

S. D. Barrington, "The Emergence of a Constitutional Court," in J. O'Reilly, Human Rights and Constitutional Law: Essays in Honour of Brian Walsh (Dublin: The Round Hall Press, 1992), p. 251.

6. Ibid., p. 255 (emphasis added).

7. D. R. Phelan, " 'It's God They Ought to Crucify,' " Working Paper E.U.I. Law No. $92 / 33$

8. Case 26/62 van Gend en Loos $v$. Nederlanse Administratie der belastingen [1963] ECR 1, 12.

9. Case 6/64 Cosıa v. ENEL [1964] ECR 585, 593-4; Case 106/77 Simmenthol [1978] ECR 629, 643-4.

10. Case 48/71 Commission v. I/aly [1972] ECR 527, 532; EC law must be "fully applicable at the same time and with identical effects over the whole territory of the Community without the Member States being able to place any obstacles in the way."

11. Goods: Art. 9, case 251/78 Denkavit [1979] ECR 3369, 3384; workers: Art. 48, case 4!/74 van Duyn [1974] ECR 1337, 1347; services: Art. S9(1) and 60(3), case 33/74 van Binsbergen [1974] ECR 1299, 1310-12; establishment: Art. 52, case 2/74 Reyners [1974] ECR 631, 651-2.

12. Case 120/78 Rewe v. Dundesmonopolverwallung fïr Branntwein (Re Cassis de Dijon) [1979] ECR 649; case 159/90 SPUC v. Grogan [1991] 3 CMLR 849.

13. Case C-106/89 Marleasing v. La Comercial [1990] ECR 4135, 4160; joined cases C-6/90 and C-9/90 Francovich and Bonafaci v. Italy [1992] Industrial Relations Law Review 84.

14. Opinion 1/91 Re the Draft Treaty on a European Economic Area [1992] 1 C.M.L.R. 245, 269 paragraph 21; see also $O$. Due, "A Constitutional Court for the European Communities," in D. Curtin and D. O'Keefe, Constitutional Adjudication in European Community and Nationat Law (1992, Dublin), p. 4.

15. Opinion 1/91 at p. 272. SEA: first recital of the Preamble. Solemn Declaration of 19 June 1983: section 2.5.

16. Sioke-on-Trent Cily Coundl v. B \& $Q$ plc., The Times 17.12.92; Case 121/85 Conegate v. HM Customs and Excise [1986] I CMLR 739.
17. For erample, in Ciermans, Imer.

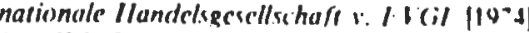

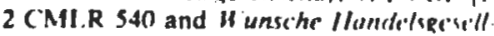
schaft [1987] 3 CMIL 225 ; in ltaly. I rmm!n! v. Minestern delle Finanze (1974) 2 C M11 R 372 and Sp.A Fragd y. Amministruzions detle Finanze (1989) 72 Revisla di Dirillo Inler. narionale 103; in Ireland, SI'C.C v. Cirngan (1992) Mfodern Law Revieu M/I RI Ss $n$. $670 ;$ in the U.K.. case C.213/89 Factortume [1990| ECR 2433.

18. D. R. Phelan, "The Normatise Shap ing of the European Union." Mfodern / aw" Revicu 5s (1992): 670.

19. "Belling the Cats: Collected Spercher and Essays of John Kelly" (IDuhlin, 1991).

20. The review of H. Rasmussen. ( $) /$ l an and Poticy in the Europkan (ourt af Justice (Martinus Nijhoff, 1986) by M. Capncllctti. The Judicial Process in Comparative Perspec tive (Oxford: Clarendon Press, 1989), r.

21. For a proposal involvine national narliaments, see L. Brittan. "Instilutional IXevel. opment of the Furonean Communit;:"

Public Law 567 (1992): 576.77.

22. The Financial Timer, 29 January 199.1.

23. Commission of the European Com: munities, From Single Market in Europeun Union (Brussels: 1992), p. 13.

24. Supra n. 12.

25. Report of the Senate on the revicion of the Constitution of the Fifth Rcpublic No. 375, 27 mai 1992, p. 94. See also Judgment of Conseit Constitutionnel, 9 April 1942. Recenil Trimestrielle de Droil Eurnpeen. 28(2) (1992): 419.

26. MacCormick, "Beyond the Sovereign State," MII.R (1993): 1, il.

27. D. R. Phielan, "The Application of United States and European Communils Domestic Trade I.aws to the Imports of Non. market Economy CATT Contracting Partics -A Time for Change," IIorkine Paper E.U.I. Law No. 92/28.

28. Op cil. supra n. 23.

\section{About the Author}

\section{(leave about $1.1 / 2$ in.. includine} PHOTO 7A: $6 \mathrm{~W} \times 8 \mathrm{H}$ ) 